Research Report No. 33/2009

\title{
The Evolution of Legal Education: Internationalization, Transnationalization, Globalization
}

Simon Chesterman

Follow this and additional works at: http://digitalcommons.osgoode.yorku.ca/clpe

\section{Recommended Citation}

Chesterman, Simon, "The Evolution of Legal Education: Internationalization, Transnationalization, Globalization" (2009). Comparative Research in Law \& Political Economy. Research Paper No. 33/2009.

http://digitalcommons.osgoode.yorku.ca/clpe/145 


\section{Comparative Research in Law \& Political Economy}

\section{Simon Chesterman}

\section{Three Conceptions The Evolution of Legal}

Education: Internationalization, Transnationalization, Globalization

EDITORS: Peer Zumbansen (Osgoode Hall Law School, Toronto, Director, Comparative Research in Law and Political Economy, York University), John W. Cioffi (University of California at Riverside), Nassim Nasser (Osgoode Hall Law School, Toronto, Production Editor)

Also available at: http://www.germanlawjournal.com 



\section{German Law Journal}

The Evolution of Legal Education: Internationalization, Transnationalization, Globalization Simon Chesterman

10 German Law Journal 877 (2009), available at:

http://www.germanlawjournal.com/article.php?id=1127

This article was originally published in Volume 10, Number 7 of the German Law Journal as part of the journal's $10^{\text {th }}$ anniversary symposium on "Transnationalizing Legal Education" edited by Nadia Chiesa, Adam de Luca, and Bernadette Maheandiran. 
CLPE Research Paper 33/2009

Vol. 05 No. 06(2009)

\title{
Simon Chesterman
}

\section{The EVOLUTION OF LEgAL EDUCATION: INTERNATIONALIZATION, Transnationalization, Globalization}

\begin{abstract}
This article examines the evolution of legal education as it has moved through international, transnational, and now global paradigms. It explores these paradigms by reference to practice, pedagogy, and research. Internationalization saw the world as an archipelago of jurisdictions, with a small number of lawyers involved in mediating disputes between jurisdictions or determining which jurisdiction applied; transnationalization saw the world as a patchwork, with greater need for familiarity across jurisdictions and hence a growth in exchanges and collaborations; globalization is now seeing the world as a web in more ways than one, with lawyers needing to be comfortable in multiple jurisdictions.
\end{abstract}

Keywords: Legal education, Transnationalization, Internationalization, Globalization

JEL classification: K10, K40

Simon Chesterman

Global Professor and Director of the New York University School of Law Singapore Program;

Associate Professor, National University of Singapore Faculty of Law.

Email: chesterman@nyu.edu 



\title{
SPECIAL ISSUE: TRANSNATIONALIZING LEGAL EDUCATION
}

\section{The Evolution of Legal Education: Internationalization, Transnationalization, Globalization}

\author{
By Simon Chesterman*
}

This article examines the evolution of legal education as it has moved through international, transnational, and now global paradigms. It explores these paradigms by reference to practice, pedagogy, and research. Internationalization saw the world as an archipelago of jurisdictions, with a small number of lawyers involved in mediating disputes between jurisdictions or determining which jurisdiction applied; transnationalization saw the world as a patchwork, with greater need for familiarity across jurisdictions and hence a growth in exchanges and collaborations; globalization is now seeing the world as a web in more ways than one, with lawyers needing to be comfortable in multiple jurisdictions.

"[L]aw is a science, and ... all the available materials of that science are contained in printed books. ... We have also constantly inculcated the idea that the library is the proper workshop of professors and students alike; that it is to us all that the laboratories of the university are to the chemists and physicists, the museum of natural history to the zoologists, the botanical garden to the botanists."

Christopher Columbus Langdell, Dean of Harvard Law School, $1887^{1}$

\footnotetext{
* Global Professor and Director of the New York University School of Law Singapore Program; Associate Professor, National University of Singapore Faculty of Law. Email: chesterman@nyu.edu. This is a revised and expanded version of a paper presented at the International Bar Association annual conference held in Singapore in October 2007 and first published in the Singapore Journal of Legal Studies. Many thanks to Gary Bell, Thomas Dreier, Richard J. Goldstone, Tan Cheng Han, and Stanley Yeo for their comments on earlier drafts. I have also profited from discussing these issues with, among others, Alex Aleinikoff, Benedict Kingsbury, Richard Stewart, and Joseph Weiler. Many thanks to Nicolás Lozada for invaluable research assistance.
}

${ }^{1}$ Christopher Columbus Langdell, The Harvard Law School, 3 L.Q. REv. 123, 124 (1887). 


\begin{abstract}
"Students trained under the Langdell system are like future horticulturalists confining their studies to cut flowers, like architects who study pictures of buildings and nothing else. They resemble prospective dog breeders who never see anything but stuffed dogs. And it is beginning to be suspected that there is some correlation between that kind of stuffed-dog study and the over-production of stuffed shirts in the legal profession."
\end{abstract}

\author{
Jerome Frank, \\ Report to the Alumni Advisory Board of the \\ University of Chicago Law School, $1932^{2}$
}

Legal education has always borne an ambiguous relationship to the practice of law. Is a law degree a technical qualification, like carpentry or medicine, or a serious field of intellectual inquiry, like philosophy? The uncertain answer to that question is evident in the fact that so many jurisdictions require a professional qualification administered by the local guild a pupillage, or a bar examination - as well as a degree in order to practice. Only a few allow lawyers to practice with only a degree, such as some civil law countries (notably in Latin America), or with only a professional certification, such as a handful of U.S. states ${ }^{3}$ and, until recently, Japan. ${ }^{4}$

How one answers the question affects more than the careers of professional lawyers: it will have important implications for how one teaches in a law school. In Australia, for example, the undergraduate law degree is increasingly regarded as a kind of upscale Arts degree - only about half of all law graduates actually end up entering the private legal profession. ${ }^{5}$ Singapore, by contrast, until recently treated law more as a technical

2 Jerome Frank, Why Not a Clinical Lawyer-School?, 81 U. PA. L. REV. 907, 912 (1932).

${ }^{3}$ National Conference of Bar Examiners \& the American Bar Association Section of Legal Education \& Admission to the Bar, Comprehensive Guide to Bar Admission Requirements 2005 (2005), available at: http://www.abanet.org/legaled/publications/compguide2005/chart3.pdf, 10-13, last accessed, 14 March 2009. Note that the requirement to attend law school in most other states is a comparatively recent phenomenon. In 1922 , no state required a law degree as a condition of admission to practice and law school was seen by many as an unnecessary delay in a legal career. Alberto Bernabe-Riefkohl, Tomorrow's Law Schools: Globalization and Legal Education, 32 SAN DiEgo L. ReV. 137 (1995).

\footnotetext{
${ }^{4}$ See generally Gerald Paul McAlinn, Reforming the System of Legal Education: A Call for Bold Leadership and Selfgovernance, 2 ASIAN-PAC. L. \& POL'Y J. 15 (2001); Setsuo Miyazawa, The Politics of Judicial Reform in Japan: The Rule of Law at Last?, 2 ASIAN-PAC. L. \& PoL'Y J. 89 (2001); Yoshiharu Kawabata, The Reform of Legal Education and Training in Japan: Problems and Prospects, 43 S. TEX. L. REV. 419 (2002); Masako Kamiya, Structural and Institutional Arrangements of Legal Education: Japan, 24 WIS. INT'L L.J. 153 (2006).

${ }^{5}$ Directory of Commonwealth Law Schools, 1999/2000 3 (John Hatchard ed., 1999); Mary Keyes and Richard Johnstone, Changing Legal Education: Rhetoric, Reality, and Prospects for the Future, 26 SYDNEY L. REV. 537 (2004).
} 
qualification, with the government's Third Committee on the Supply of Lawyers capping the number of law students at the estimated number of lawyers required in the republic. ${ }^{6}$ As a result, Australia has more than six times as many law students per capita $-28,000$ compared to around 1,000 in Singapore, ${ }^{7}$ or one student for every 700 people in Australia as opposed to one for every 4,600 in Singapore - but has also embraced a more critical and theoretical approach to the study of law.

This article focuses not on how legal education is changing within any particular jurisdiction, but as a result of transformations across jurisdictions. ${ }^{8}$ In some ways this is hardly a novel phenomenon; law has previously been spread through the expansion of empire in the form of Roman law (at least as it applied to Roman citizens) and the Napoleonic code. ${ }^{9}$ The difference now is that the engine of change is not top-down politics but bottom-up practice. The transformations identified here have been led, first, by the profession, as changes in the way law is practiced have necessitated a change in the way in which it is taught. Such influences are linked to developments in transportation and communication and the enmeshing of diverse economies embraced by the loose term "globalization". A second influence has been the more mobile student population that law schools confront, with immigrants, expatriates, and exchange students making up ever larger proportions of our classes. ${ }^{10}$ Thirdly, there has also been an intellectual shift, as those of us studying the law realized that there was far more to be gained from comparative analysis and, more recently, that something interesting was happening that transcended traditional jurisdictional analysis.

These influences have seen legal education move away from a purely local approach and through three broad paradigms, which one might term "international", "transnational",

\footnotetext{
${ }^{6}$ Such a practice is hardly unique to Singapore. See, e.g., Hikmahanto Juwana, Legal Education Reform in Indonesia, 1(1) ASIAN J. COMP. L. (2006).

${ }^{7}$ See, e.g., Ministry of Education (Singapore), Establishment of the Singapore Management University School of Law (5 January 2007), available at: http://www.moe.gov.sg/press/2007/pr20070105.htm, last accessed, 14 March 2009.

${ }^{8}$ It is beyond the scope of this article to consider in detail the various transformations in education within Europe, through programs such as Erasmus and the European Credit Transfer System (ECTS). For a discussion, see Norbert Reich, Recent Trends in European Legal Education: the Place of the European Law Faculties Association, 21 PENN ST. INT'L L. REV. 21 (2002).

${ }^{9}$ TAN Cheng Han, Change and Yet Continuity - What Next After 50 Years of Legal Education in Singapore?, [2007] SINGAPORE J. LEGAL STUD. 201, 203 (2007).

${ }^{10}$ See, e.g., Lana M. Manitta, Broken Barriers in Legal Education: How Immigration and Integration Have Shaped the Way We Learn the Law, 12 GEO. IMMIGR. L.J. 361 (1998); Carole Silver, Internationalizing U.S. Legal Education: A Report on the Education of Transnational Lawyers, 14 CARDOZO J. INT'L \& COMP. L. 143 (2006).
} 
and now "global" approaches to legal education. ${ }^{11}$ The following three parts will explore these paradigms in turn by considering what each has meant for practice, pedagogy, and research. Part D considers two possible critiques of the move towards globalization in legal education - that it is primarily a discourse of the rich, and that "globalization" often means "Americanization". The conclusion sketches out some possible futures.

\section{A. Internationalization}

The law school - particularly the American law school as we understand it - is in many ways a twentieth century invention. Though Harvard's Christopher Columbus Langdell famously invented the modern common law curriculum in the $1870 \mathrm{~s},{ }^{12}$ it was only in 1921 that the American Bar Association recommended that admission to practice be linked to completion of a degree program. ${ }^{13}$ This was distinct from the English tradition, according to which lawyers were educated not in universities but in court. ${ }^{14} \mathrm{~A}$ different approach had long existed in civil law jurisdictions where Roman law was taught, beginning with its rediscovery at the University of Bologna in the 11th century. ${ }^{15}$ Interestingly, courses in Roman law were also offered at universities such as Oxford and Cambridge - though they had little practical application.

Even with the standardization of legal education in common law jurisdictions, the guild-like nature of the profession encouraged a focus not merely on national but on sub-national jurisdictions. In the United States, for example, admission to practice in one state did not require either familiarity with or the ability to practice in another. ${ }^{16}$ As interstate commerce and thus cross-jurisdictional legal practice increased, so did the need for lawyers to be familiar with other jurisdictions and, with the movement of professionals, to have a means of transferring accreditation. ${ }^{17}$

\footnotetext{
${ }^{11}$ This schema broadly corresponds to that presented in by Alex Aleinikoff at a panel at the American Society of International Law annual meeting in 2007 and subsequently published as T. Alexander Aleinikoff, Remarks on the Globalization of the American Law School, 101 Proc. AM. SOC'Y INT'L L. 184 (2007).

${ }^{12}$ Howard Schweber, Langdell, We Hardly Knew Ye, 17(1) LAW AND HISTORY REVIEW 145 (1999).

${ }^{13}$ James P. White, Rethinking the Program of Legal Education: A New Program for the New Millennium, 36 TULSA L.J. 397,400 (2000).

${ }^{14}$ KonRAD ZWEIGERT AND Hein KötZ, Introduction to Comparative LaW (3rd ed. 1998).

${ }^{15}$ Henry Mather, The Medieval Revival of Roman Law: Implications for Contemporary Legal Education, 41 CATH. LAW. 323 (2002)

${ }^{16}$ Colin Croft, Reconceptualizing American Legal Professionalism: A Proposal for Deliberative Moral Community, 67 N.Y.U. L. REV. 1256, 1296 (1992).

${ }^{17}$ Compare George A. Reimer, A State of Flux: Trends in the Regulation of the Multijurisdictional Practice of Law, 64 OREgon State BAR Bulletin 19 (August-September, 2004).
} 
Similar things happened in the first phase of transformation identified here as internationalization. As a modest advance on a purely local conception of the law, this international paradigm saw the world as an archipelago of jurisdictions, with a small number of lawyers involved in mediating disputes between jurisdictions or determining which jurisdiction applied. This is the world of traditional international law, with a majority of practice taking place within a given jurisdiction and educational institutions thus focusing on training students for that purpose. ${ }^{18}$

Specialized areas of practice and research developed within this paradigm. One was conflict of laws (or private international law) as the sub-discipline that helped to identify which jurisdiction applied to a specific problem. A second was public international law, which - despite a voluminous secondary literature - was applied in formal judicial processes in the far fewer actual cases of interactions between jurisdictions as states. ${ }^{19}$ Though comparative law also went through a phase of development around this time, it was seen as largely confined to academic study rather than being integral to the practice of law. $^{20}$

Students within this period rarely moved. The vast majority studied in the jurisdiction in which they lived and within which they would practice, with the exception of those living under colonial rule who might be sent to the metropole for instruction and recruitment into the ruling class. ${ }^{21}$

\section{B. Transnationalization}

The term "transnational law" is commonly attributed to Philip C. Jessup's Storrs Lectures at Yale in the 1950s, where he used the term to embrace "all law which regulates actions or events that transcend national frontiers."22 For present purposes, it denotes the shift in

\footnotetext{
${ }^{18}$ Again, a contrast may be made with civil law education, which had a far richer tradition of exchanging faculty and ideas based on a shared heritage.

${ }^{19}$ Compare Martti Koskenniemi, The Gentle Civilizer of Nations: The RISE ANd Fall Of International LaW 1870-1960 (2001).

${ }^{20}$ Singapore, unusually, has included the study of comparative law as a compulsory subject at both its law schools. Harvard has added this more recently. Tan, supra note 9 at 204.

${ }^{21}$ Until the early 1960s, for example, most of Anglophone Africa's lawyers were trained in Britain. Many of the national programs that developed subsequently emphasized preparation for practice at the expense of critical analytical skills. Though such a criticism might also be made of American and European legal training, graduates typically begin work with more experienced colleagues. This was not always possible when starting up a domestic legal profession in the period of decolonization. Muna Ndulo, Legal Education in Africa in the Era of Globalization and Structural Adjustment, 20 PENN ST. INT'L L. REV. 487 (2002).

${ }^{22}$ Philip C. Jessup, Transnational LaW (1956).
} 
perspectives that came slightly later, in the 1970s and 1980s, where the world came to be seen not as an archipelago but as a patchwork of jurisdictions. The increasing mobility of capital and people required, and made possible, greater familiarity across jurisdictions. Within law schools, this took the form of collaborations and exchange programs. ${ }^{23}$

Practice continued to be jurisdiction-based, but this period saw the rise of firms with presences in many cities - acknowledging the need to be able to operate seamlessly when moving from one jurisdiction to another. ${ }^{24}$ Law schools began to offer summer programs abroad: in the United States in 1975, five American Bar Association (ABA)-approved law schools offered such programs; a generation later 120 law schools did. ${ }^{25}$ Some were regarded as little more than boondoggles. In the 1976-77 academic year, for example, the ABA's Accreditation Committee received notice of a program to be offered onboard a cruise ship: courses were to be taught by faculty from an unaccredited law school, excessive credit was to be awarded for the period of study, and there appeared to be no library or study facilities available to the "students". ${ }^{26}$ But, for the most part, these programs demonstrated a desire on the part of students to get some measure of experience outside their home jurisdiction.

Of more lasting significance was the increase in exchange programs and the rise in the number of foreign students admitted into law degree programs. The National University of Singapore, for example, today has one of the most extensive exchange arrangements in the world. More than a third of its undergraduate law students spend a semester or full year on exchange to one of more than fifty universities in sixteen countries, with a corresponding number of students coming from abroad to study in Singapore. ${ }^{27}$

\footnotetext{
${ }^{23}$ From 2004, the University of Michigan began requiring students to complete a course in "Transnational Law" prior to graduating. See Mathias Reimann, Taking Globalization Seriously: Michigan Breaks New Ground by Requiring the Study of Transnational Law, 82 MicH. B.J. 52 (2003).

${ }^{24}$ Skadden, Arps opened its first office outside of New York in 1973; Allen \& Overy opened its first office outside of London in 1978. Today Clifford Chance has 28 offices in 21 countries. About Clifford Chance (2008), available at: http://www.cliffordchance.com/about_us/about_the_firm/?LangID=UK\&, last accessed, 14 March 2009.

${ }^{25}$ James P. White, A Look at Legal Education: The Globalization of American Legal Education, 82 IND. L.J. 1285, 1287 (2007).

${ }^{26} / d$. Thirty years later, Tulane University also proposed to house students on a cruise ship, though this was part of the response to devastation wrought by Hurricane Katrina in New Orleans the previous year. Piper Fogg, At Tulane, Living on a Cruise Ship Is No Luxury Vacation, 52(20) CHRON. HIGHER EdUC. A14 (2006).

${ }^{27}$ For a discussion of how the National University of Singapore's approach to education has evolved, see Alexander Loke, Forging a New Equilibrium in Singapore Legal Education, 24 WIS. INT'L L.J. 261 (2006); Tan, supra note 9.
} 
The increasing diversity of the student population has had an important effect on the classroom, though a further shift is in process now as the movement across jurisdictions of transnationalization has given way to the emergence of a single globalized market.

\section{Globalization}

The third phase of evolution of legal education is where we are now: globalization. ${ }^{28}$ This can be understood as the integration of countries and peoples brought about by deep reductions in the costs of transport and communication, and the dismantling of barriers to the flow of goods, services, capital, knowledge, and people. ${ }^{29}$

The world has moved from archipelago to patchwork to web - both in the sense of the rise of the Internet as well as in the sense that commercial and other activities do not simply overlap at the edges but may be structurally and inextricably linked. Leading law firms increasingly present themselves as "global", a status measured for the first time in 1998 when the American Lawyer first published its "Global Fifty" list of firms ranked by size and revenue. ${ }^{30}$ This has been augmented by the increasing importance of non-traditional regulatory regimes that transcend traditional jurisdictional analysis. Whether it is compliance with ISO standards, controlling the behaviour of multinational corporations, or - to pick the most obvious example - regulation of the Internet itself, contemporary normative questions are frequently global rather than local. ${ }^{31}$

To operate effectively in such a world, individual lawyers need to be comfortable in multiple jurisdictions, often simultaneously. ${ }^{32}$ In the words of one dean, we need to educate lawyers to be "residents" rather than "tourists" in new jurisdictions. ${ }^{33}$ At the same time, the students entering law school are different. In the course of the twentieth century, we moved from a tradition of a person having one job as a career to expecting to move jobs once or twice. ${ }^{34}$ We now deal with students who expect to move countries a few times, seeing themselves as part of a global elite in a worldwide market for talent.

${ }^{28}$ See generally John E. Sexton, "Out of the Box": Thinking About the Training of Lawyers in the Next Millenium, 33 U. TOL. L. REV. 189 (2001).

${ }^{29}$ See Joseph E. Stiglitz, Globalization And Its Discontents 9 (2002).

${ }^{30}$ John E. Morris, The Global 50, AM. LAW., November 1998, 45.

${ }^{31}$ See generally Benedict Kingsbury, Nico Krisch, and Richard B. Stewart, The Emergence of Global Administrative Law, 68 LAW \& CONTEMP. PROBS. 15 (2005); Simon Chesterman, Globalization Rules: Accountability, Power, and the Prospects for Global Administrative Law, 14 GLoBAL GovernANCE 39 (2008).

${ }^{32}$ TAN Cheng Han, Law School Has to Keep Up with the Times, STRAITS TIMES, 26 April 2007.

${ }^{33}$ Mary C. Daly, Tourist or Resident?: Educating Students For Transnational Legal Practice, 23 PENN ST. INT'L L. REV. 785 (2005)

${ }^{34}$ One study estimated that lawyers beginning in small U.S. firms move once every eight years; another found that within six years of graduating from law school, almost half of lawyers in private practice and almost two-thirds of 
Within legal education, the first mark of globalization as distinct from transnationalization was the move from exchange programs to double-degree programs across national jurisdictions. Examples from the United States include Cornell University Law School, which offers double-degrees in partnership with universities in France and Germany; ${ }^{35}$ Columbia Law School, which also has partners in France and Germany as well as England; ${ }^{36}$ New York University School of Law (NYU), which partners with Osgoode Hall Law School in Canada and the National University of Singapore; ${ }^{37}$ and American University Washington College of Law, which includes partner universities in Canada, Spain, France, England, the Netherlands, Hong Kong, Korea, South Africa, and Uganda. ${ }^{38}$

Such double-degrees are essentially an extension of traditional exchange programs. Though reflecting the value of holding qualifications in multiple jurisdictions, as an academic credential such programs are based on the recognition of transfer credits from the partner institution, typically involving some measure of double-counting in order for the double-degree to take less time than earning the two degrees seriatim. More interesting intellectually is when law schools actually start teaching together.

The NYU School of Law and National University of Singapore Dual Degree Program, known informally as "NYU@NUS", is a move in this direction. ${ }^{39}$ It offers master of laws degrees from each of the partner institutions, but is taught entirely in Singapore with NYU faculty flying out during the northern summer months; students then stay on to take courses with NUS and visiting faculty. Its origins lie in a 2002 conversation between NUS Dean Tan Cheng Han and then Director of NYU's global program Joseph Weiler when they realized that they were both seeking to offer a new form of education that reflected the way

those in government were no longer working with their first employer. Ronit Dinovitzer and Bryant G. Garth, Lawyer Satisfaction in the Process of Structuring Legal Careers, 41 LAW \& SOC'Y REV. 1 (March 2007).

${ }^{35}$ Cornell University Law School, Dual Degrees, available at: http://www.lawschool.cornell.edu/admissions/ degrees/dual_degree.cfm, last accessed, 14 March 2009.

${ }^{36}$ Columbia Law, Foreign Double Degree Programs, available at: http://www.law.columbia.edu/center_program/ intl_progs/ Double_degrees, last accessed, 14 March 2009.

${ }^{37}$ New York University School of Law, available at: http://www.law.nyu.edu, last accessed, 14 March 2009. (This refers to the LL.B.-J.D. and LL.B.-LL.M. double-degree programs. The dual degree program taught together with NUS will be discussed below.)

${ }^{38}$ American University Washington College of Law, Admissions, available at: http://www.wcl.american.edu/ admissions.cfm, last accessed 14 March 2009.

${ }^{39}$ A different model can be seen in the Temple University and Tsinghua University LL.M. Program based at Tsinghua University, primarily intended for Chinese-educated students. See, Graduate Masters Law Beijing, available at: http://www.law.temple.edu/servlet/RetrievePage?site=TempleLaw\&page=Graduate_Masters _Law_Beijing, last accessed 14 March 2009. 
students were increasingly required to think and to practice: globally. What is novel about the approach is that it is a genuine collaboration between the two institutions, going beyond the exchange model to integrate courses into a whole that is greater than the sum of its parts.

The first year (being the academic year 2007-2008) of the program, which I direct, attracted thirty-nine students from twenty-one countries across six continents. When planning the program, it had been assumed that two broad categories of students would apply: first, Asian students who aspire to an American legal qualification but choose not to base themselves in the United States; and, secondly, American and European students who recognize the benefit of an NYU-brand degree, but see their intellectual or professional future in Asia. The partnership with NUS is an attraction in its own right, due to the extensive offerings in region-specific subjects as well as partnerships such as that with the East China University of Politics and Law, allowing the possibility of completing some of the NUS LL.M. in Shanghai. ${ }^{40}$

Interestingly, we had assumed that the largest contingent would be in the first, Asian, category - in fact Asians made up less than half of the inaugural cohort. In the second year of the program, over fifty students from two dozen countries enrolled, once again touching every continent and with well under half from Asia itself. This reflects the extraordinary international interest in Asia as the future of globalization, as well as the suitability of Singapore in general and NUS in particular as a gateway to that region. Such collaborations seem likely to be replicated elsewhere, much as NYU's "global law school", first conceived in $1993,{ }^{41}$ has become a touchstone adopted by other leading law schools such as Harvard ${ }^{42}$ and Yale. ${ }^{43}$

\section{Two Critiques}

The above description of the changing paradigms of legal education is not intended to suggest that the evolution that has taken place is either equitable or progressive in the political sense of the term. Indeed, on the face of it the exact opposite would appear to be true, as the ability of graduates to enter into the top jobs is increasingly tied to their ability

\footnotetext{
${ }^{40}$ The NYU@NUS program is the foundation for increasingly close cooperation between the two law schools, which recently launched combined LL.B.-LL.M. and LL.B.-J.D. programs. In addition to degree programs, greater faculty collaboration in teaching and research will enrich the intellectual life of both institutions.

${ }^{41}$ Norman Dorsen, Achieving International Cooperation: N.Y.U.'s Global Law School Program, 51 J. LEGAL EdUc. 332 (2001).

${ }^{42}$ Harvard: A Global Law School (interview with Bill Alford), available at: http://www.law.harvard.edu/news/ today/2002/11/5alford.php, last accessed 14 March 2009.

${ }^{43}$ Yale Law School, International Law, available at: http://www.law.yale.edu/internationallaw.htm, last accessed 14 March 2009, (describing Yale as a "first-class global law school").
} 
to study in the most expensive or exclusive institutions. Is this new global legal education, then, simply a discourse of the rich? ? $^{44}$

It is. Or rather, it is true that we are indeed talking about the privileged few, but one has always been able to make that argument about lawyers. In this context, a small ray of hope in the phenomenon of global legal education is that it is essential for lawyers to be able to cope with diversity. This offers an incentive - heavily litigated in the United States - for law schools to use scholarships to expand opportunities to candidates that are diverse in every sense. ${ }^{45}$ Nevertheless, the emergence of "global law schools" will certainly be an elite phenomenon. ${ }^{46}$

A second critique that might be made of the phenomenon and the way it has been described in this article is that what is occurring is not so much globalization as Americanization. This is also partly accurate, reflecting the U.S. dominance in the practice of law and its cultural influence more generally. Of the "Global Fifty" law firms cited earlier, ${ }^{47}$ thirty of the top firms by size were American; when ranked by revenue all but seven were. ${ }^{48}$ Within the academic world, one can see the shift of English-speaking educational pedigrees from Oxbridge to the United States (for example within the faculty of the National University of Singapore ${ }^{49}$ ) as well as the gravitational effect of U.S. institutions on pedagogy and U.S. journals on research.

The U.S. model of legal education has also exerted its own pull, clearly influencing reform initiatives in Japan and Korea, which have moved to adopt J.D.-style graduate law degrees. ${ }^{50}$ The same may happen in Australia, where the University of Melbourne has

\footnotetext{
${ }^{44}$ Compare Tamar Lewin, U.S. Universities Rush to Set Up Outpost Abroad, N.Y. TIMES, 10 February 2008.

${ }^{45}$ See, e.g., Rachel F. Moran, Of Doubt and Diversity: The Future of Affirmative Action in Higher Education, 67 ОноО ST. L.J. 201 (2006).

${ }^{46}$ Tan, supra, note 9 at 206-207.

${ }^{47}$ See, supra, note 30.

${ }^{48}$ Morris, supra, note 30; Silver, supra note 10 at 146.

${ }^{49}$ A loose measure is to look at the highest level degrees held by the different levels of academics on the faculty: Professors and above (6 Oxbridge, 4 U.S.); Associate Professors (11 Oxbridge, 13 U.S.); Assistant Professors (1 Oxbridge, 7 U.S.). (This excludes faculty on long-term secondment.)

${ }^{50}$ Tom Ginsburg, Transforming Legal Education in Japan and Korea, 22 PENN ST. INT'L L. REV. 433, 437 (2004); Kyong-Whan Ahn, Law Reform in Korea and the Agenda of "Graduate Law School", 24 WIS. INT'L L.J. 223 (2006); Chang Rok Kim, The National Bar Examination in Korea, 24 WIS. INT'L L.J. 243 (2006). For a discussion of similar debates in Taiwan, see Chang-fa Lo, Driving an Ox Cart to Catch Up with the Space Shuttle: The Need for and Prospects of Legal Education Reform in Taiwan, 24 WIS. INT'L L.J. 41 (2006).
} 
adopted a similar approach. ${ }^{51}$ Comparable developments appear to be underway in Hong Kong $^{52}$ and the Philippines, ${ }^{53}$ where the J.D. is offered alongside the LL.B.

Nevertheless, programs like NYU@NUS also exemplify the limitations of the U.S. model and a recognition (by Americans and others) that a truly global legal education requires not simply the exporting of U.S. ideas but a genuine engagement with the people and the places that make up today's global profession.

\section{E. Conclusion}

As an Australian educated in Europe working for an American law school based in Asia, these reflections are of more than academic interest. The transformations driven by changes in the practice of the law, by the types of students pursuing degrees, and somewhat belatedly - by research developments in the loosely defined area of "global law" have radically changed the nature of legal education. This is true even if not all law schools have recognized this, and these forces are going to continue exerting pressure as the notoriously protectionist world of lawyers becomes exposed to market forces. Professions such as law that have inherited the characteristics of guilds are notoriously resistant to change. ${ }^{54}$ Yet, as we have seen, law has moved from internationalization to transnationalization, and then to globalization in the space of about a generation each. Moving forward, some things will remain constant but many others will change.

One constant is that basic law degrees will remain within the province of individual jurisdictions. (Similarly, admission to practice will continue to be controlled at the jurisdictional level - though there will be pressure from industry to liberalize the recognition of foreign-trained lawyers.) Nevertheless, the push for standardization in the global market for legal talent will encourage more states to move in the direction of an American-style J.D. graduate law degree. England will probably remain an outlier with its three-year undergraduate program, but a higher proportion of its students will seek graduate qualifications elsewhere. The content of the basic law degree will continue to emphasize the traditional subjects, but the move away from the memorization of black-

\footnotetext{
${ }^{51}$ See Melbourne Law School <http://jd.law.unimelb.edu.au>.

${ }^{52}$ See Chinese University of Hong Kong, available at: http://www.cuhk.edu.hk/law/prospectiveStudents/jd.html, last accessed 14 March 2009; City University of Hong Kong, available at: http://www.cityu.edu.hk/slw/ english/programmes/courses/jd.htm, last accessed 14 March 2009.

53 Ateneo Law School, available at: http://law.ateneo.edu/index.php?p=32\&PHPSESSID=97d98dc928359b387 8cd843fd362e354, last accessed 14 March 2009; Far Eastern University Institute of Law, available at: http://www.feu.edu.ph/il.php last accessed 14 March 2009.

${ }^{54}$ Herbert M. Kritzer, The Future Role of "Law Workers": Rethinking the Forms of Legal Practice and the Scope of Legal Education, 44 ARIz. L. REV. 917 (2002).
} 
letter law will become irresistible: faculties will seek ways to ensure that their graduates are both intellectually and culturally flexible, capable of adapting not merely to new laws but to new jurisdictions. Comparative and international subjects will receive greater emphasis, with comparative and international perspectives also being introduced to a wider range of subjects. There will be resistance, but not for long. ${ }^{55}$

In addition, at least some international experience will increasingly be seen as essential to the practice of law at the upper echelons, with more law schools offering exchange and double-degree programs. Early collaborations were transatlantic, but many future tie-ups will focus on Asia, recognizing the important role that Asia now plays in economic terms and the role it will assume - eventually - in political and cultural terms. ${ }^{56} \mathrm{~A}$ second locus will be the Gulf, offering enormous financial resources but less conducive to genuine partnership given the dearth of English-language scholarly institutions. As universities seek to take advantage of these opportunities, there is a danger of overstretching resources and diluting brand names: some partnerships will be established that work well for a couple of years but become unsustainable; other relationships that primarily exist on paper will eventually be seen as compromising the reputation of one or both institutions. The push towards globalization is unlikely to diminish, but there will be both successes and failures as law schools attempt to adapt.

Oliver Wendell Holmes, Jr. once noted that "[t]he life of the law has not been logic: it has been experience. ${ }^{\prime 57}$ Though he was speaking of the common law, this is at least partly true of legal education. Where universities are often the driving force of advances in areas of scientific research, professional schools frequently lag behind. Law's ambiguous status as both a professional qualification and a subject of serious research has seen it evolve fitfully, driven by the demands of the profession and the needs of students, with pedagogy often being more ex post justification than forward looking agenda. It is an exciting time to teach law, but an even more exciting time to study it.

\footnotetext{
${ }^{55}$ Compare Max Planck's observation that "a new scientific truth does not triumph by convincing its opponents and making them see the light, but rather because its opponents eventually die, and a new generation grows up that is familiar with it". Quoted in THOMAS S. KUHN, THE STRUCTURE OF SCIENTIFIC REVOLUTIONS 151 (3rd ed. 1996).

${ }^{56}$ See Kishore Mahbubani, The New Asian Hemisphere: The IrResistible Shift of Global Power to the East (2008).

${ }^{57}$ Oliver Wendell Holmes, Jr., Lecture I, in The Common LAw 5 (Mark DeWolfe Howe ed., 1962).
} 